\title{
Energy production from renewable sources in Alpine protected areas Conflicting interests and need for action as seen by protected areas management
}

\author{
Esther Volken, Thomas Scheurer, Guido Plassmann \& Astrid Wallner
}

Abstract

With the growing demand for renewable energy, the conflict potential between energy production from renewable sources and maintaining protection targets is likely to increase. The study "Energy production from renewable sources in Alpine protected areas" examined the situation in Alpine parks today and the need for action from the viewpoint of park managements. Based on interviews with 21 Alpine protected areas in Austria, France, Germany, Italy and Switzerland, the study shows the conflicts and the conflict potential as well as possible strategies. The interviews revealed that there is no remedy that applies to all parks. The need for action varies depending on the potential for conflict. Thus only some of the parks would prefer stricter rules, and energy targets or concepts are judged differently. Regardless of the path that a park chooses to follow, it will be unavoidable to deal with the issue.

The study was devised by the Swiss Academy of Arts and Sciences (SAS) with the support of the Alpine Network of Protected Areas (ALPARC) and was funded by the Federal Office for the Environment (FOEN). The report "Energy production from renewable sources in Alpine protected areas" has recently been published and can be downloaded on the internet. The following article summarizes the most important findings.

\section{Introduction and motive}

Energy production from renewable sources is increasing due to both the growing demand for energy and the negative impacts of fossil fuels. As a result, Alpine protected areas (parks) are increasingly confronted with projects that aim to use water, wind, sun or biomass to generate electricity. Such projects run counter to the (conservation) targets of Alpine protected areas and therefore lead to a conflict of interests.

The study presented here examined the significance of using renewable energy sources in Alpine protected areas and focused on the following questions: Is there potential for conflict? Is there need for action? Do park managements have targets and rules concerning the use of renewable energy sources in their protected areas? The findings described below are based on interviews with members of park managements or energy experts of Alpine parks in Austria, France, Germany, Italy and Switzerland.

\section{Approach}

In order to evaluate the conflict potential between energy production from renewable sources and targets of Alpine protected areas, we needed the support of park managements. For a broad view, we asked 40 parks in the Alpine area, of which 21 parks in Austria, France, Germany, Italy and Switzerland participated in the study. They cover the most important park categories. Based on a questionnaire, energy experts or members of the park management provided facts and opinions on actual energy production from renewable sources, planned and rejected projects, conflicts between production and protection targets, legal foundations as well as targets and strategies for energy production from renewable sources.

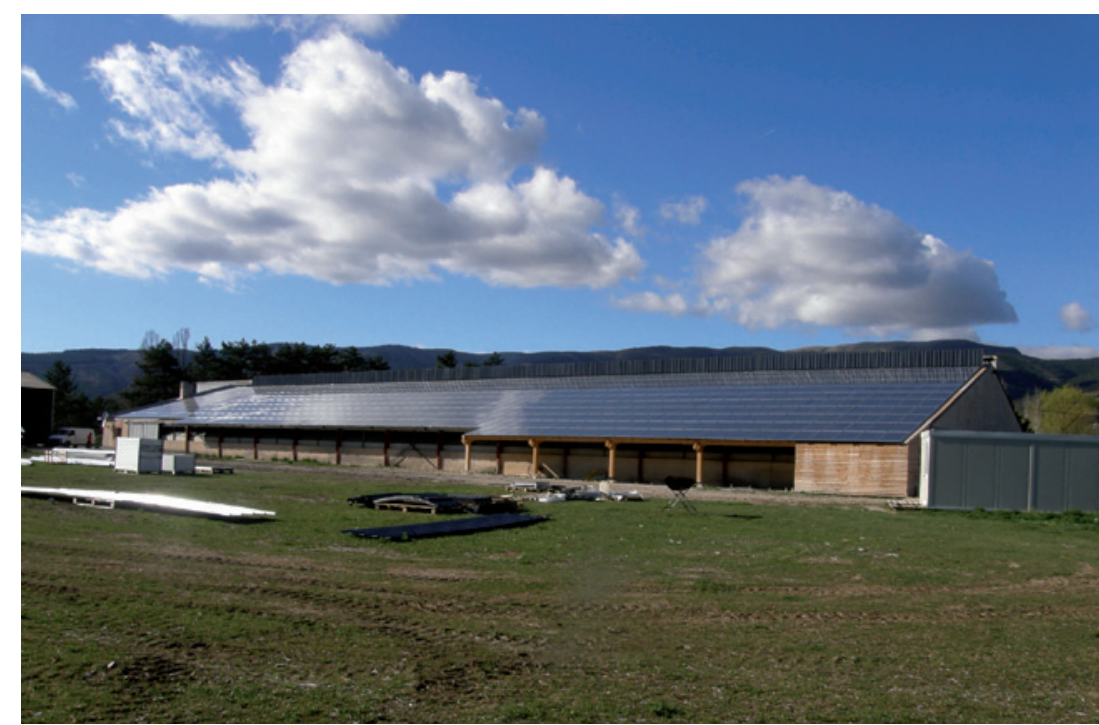

Photovoltaic plant. Baronnies Provençales Regional Nature Park. (C) Syndicat Mixte des Baronnies Provençales

The 21 parks involved in the survey cover an area of $13000 \mathrm{~km}^{2}$ or $28 \%$ of the entire protected area in the Alps. They included 13 regional nature parks, 3 biosphere reserves (BR), 4 national parks (NP) and 2 UNESCO World Heritage Sites (WHS), see Table 1. BRs and NPs zone their total area with a graduation in the degree of protection. Nature parks and UNESCO world heritage areas, on the other hand, do have areas with clearly defined protection provisions, but there is no continuous zoning of these areas in the countries involved, except for Italy. The study showed that this difference affects the potential for conflict and, consequently, also the perceived need for action. 
Table 1 - Protected areas involved in the survey.

\begin{tabular}{|c|c|}
\hline Country & Protected area \\
\hline \multirow[t]{5}{*}{ Austria } & Gesäuse National Park \\
\hline & UNESCO Biosphere Reserve Grosses Walsertal \\
\hline & Hohe Tavern National Park \\
\hline & Ötztal Nature Park \\
\hline & Tyrolean Nature Conservation Areas \\
\hline \multirow[t]{4}{*}{ France } & Baronnies Provençales Regional Nature Park \\
\hline & Chartreuse Regional Nature Park \\
\hline & Vercors Regional Nature Park \\
\hline & Verdon Regional Nature Park \\
\hline Germany & Berchtesgaden National Park \\
\hline \multirow[t]{3}{*}{ Italy } & $\begin{array}{l}\text { Adamello-Brenta Regional Nature Park and } \\
\text { UNESCO World Heritage Site }\end{array}$ \\
\hline & Friulian Dolomites Regional Nature Park \\
\hline & Gran Paradiso National Park \\
\hline \multirow[t]{8}{*}{ Switzerland } & Binntal Regional Nature Park \\
\hline & Ela Regional Nature Park \\
\hline & UNESCO Biosphere Reserve Entlebuch \\
\hline & Gantrisch Regional Nature Park \\
\hline & Pfyn-Finges Regional Nature Park \\
\hline & $\begin{array}{l}\text { Swiss Alps Jungfrau-Aletsch UNESCO World Herit- } \\
\text { age Site }\end{array}$ \\
\hline & Thal Regional Nature Park \\
\hline & $\begin{array}{l}\text { Regional Nature Park Biosfera Val Müstair (part of } \\
\text { the UNESCO Biosphere Reserve Val Müstair-Parc } \\
\text { Naziunal) }\end{array}$ \\
\hline
\end{tabular}

\section{Differing views on the need for action}

National Parks and Biosphere Reserves

All NPs and BRs involved in the survey see little or no need for action with regard to the production of energy from renewable sources. This is mainly because in NPs the strict protection of core zones makes it impossible to realize larger energy production facilities. Nor can such facilities be built in the core zones of BRs. NPs and BRs usually have defined targets for the buffer and transition zones and encourage the use of renewable energy sources in their aim for sustainable development.

Unlike NPs and BRs, regional nature parks generally do not have continuous zoning with a graduation in the degree of protection. However, all parks contain areas with clearly defined protection provisions. In principal, UNESCO world heritage areas belong to the unzoned park areas. The Swiss Alps JungfrauAletsch UNESCO WHS in the survey is a special case in this respect. Almost its entire area overlaps with areas of the Federal Inventory of Landscape and Natural Monuments of National Importance (BLN) or other cantonal or national reserves with strict requirements for the protection of landscape, species and environment. This is why the Swiss Alps Jungfrau-Aletsch UNESCO WHS sees no need for action.

Regional Nature Parks

In contrast, regional nature parks, especially the parks in Switzerland, Austria and Italy, almost unanimously see the situation differently. They do face conflicts be- tween demands for energy produced from renewable sources and protection targets and therefore most of them see the need for action. Only the French nature parks in the study consider the situation less critical.

All Swiss regional nature parks have experienced conflict situations. As the park managements have no legal competences, they generally try to assume a mediating role between conflicting interests and parties. To improve the handling of conflict situations, Swiss parks recommend encouraging transparent communication, developing strategies for dealing with projects and / or formulating framework conditions. Two of the Swiss regional nature parks in the study are currently developing energy concepts to expand the production of renewable energy without reducing nature and landscape values.

In Austria, the Ötztal Nature Park and the Tyrolean Nature Conservation Areas have been confronted with conflicts between protection and use, in particular with regard to hydroelectric power generation. In part, these conflicts are the result of competing usage interests. More concrete and clear rules would be welcomed. The province of Tyrol has developed principles for hydroelectric power generation and involved different interest groups in the process. It is not possible at this stage to assess whether the catalogue of criteria for the use of water will help to move the situation on. In addition, the Ötztal Nature Park will formulate independent targets for the promotion of renewable energy within its mission statement 2020.

Both regional nature parks in Italy also see a need for action, although rules exist in both parks, for instance, with regard to the use of water. However, these rules are not thought of as satisfactory. Whereas the Friulian Dolomites Regional Nature Park would prefer stricter rules, the Adamello-Brento Regional Nature Park considers the park legislation as rather too strict as it makes it difficult or impossible to establish even very small facilities, for instance, to supply mountain huts with energy.

The four regional nature parks in France that participated in the study see no special need for action. In cases of conflict, they rely on the targets stated in the park charter, on their own strategies or on negotiations with the organizations in charge of implementing that project.

\section{Implications from the survey}

Production of energy from renewable sources in protected areas holds potential for conflicts and park managements are aware of this. Use and protection are often considered as irreconcilable opposites. Not all parks are currently affected by conflicts to the same extent. The number of conflicts is likely to increase because the demand for the production of renewable energy will grow. 
Rules can reduce the potential for conflict

The study presented here has shown that clear rules be it a National Park Act or continuous zoning of the protected area (mainly in NPs and BRs) - may simplify the situation in respect of conflicts with energy production from renewable sources. Conflicts between demands for renewable energy and the interests of nature protection and landscape conservation occur more often in regional nature parks, because clear rules only exist for areas with defined protection functions. The task of regional nature parks is also made more difficult by the fact that they are obliged to protect nature and landscape values on the one hand and to further sustainable economic development on the other. However, conflicts about energy production from renewable sources are not necessarily seen as negative. They may also encourage discussion and an awareness of the balance between nature protection and economic development.

A delineation of areas that deserve protection can help to avoid conflict because it reduces opposition to using the potential in the remaining areas. Evidence for this can be found in the BRs of our study where the core zones must not be used for energy generation. Increasingly, regional nature parks formulate energy concepts or include energy targets in their mission statements in order to compensate for clear rules like those that exist in zoned park areas.

Park managements have little influence on facilities established in the surroundings of park areas, even if such constructions might severely affect protected areas.

Potential for conflict of different renewable energy sources

Hydroelectric power generation: In Switzerland, the potential for large facilities has already been largely realized. For small hydro-electric power plants, the potential for conflict may even increase in the near future due to the growing promotion of renewable energy sources. In Austria, hydro-electric power generation is currently strongly promoted, particularly in Tyrol and there is a large number of projects. In Italy, park legislation in combination with regional regulations guide the use of water for power generation. Park managements differ in how they rate the level of regulation: where the rules are very strict, a relaxation of the rules would be appreciated. Where legislation is lax, more stringent rules would be welcome.

Wind turbines: The use of wind for power generation is generally very conflict-ridden. Almost all projects are opposed by landscape conservation organizations. The impact on landscape and scenery, the threat to birds and bird migration as well as noise appear to be the most important arguments against wind turbines.

Utilization of biomass: With regard to energy production from biomass, the use of wood appears to be problematic in some regions. The potential for conflict arises mainly from competing interests and the

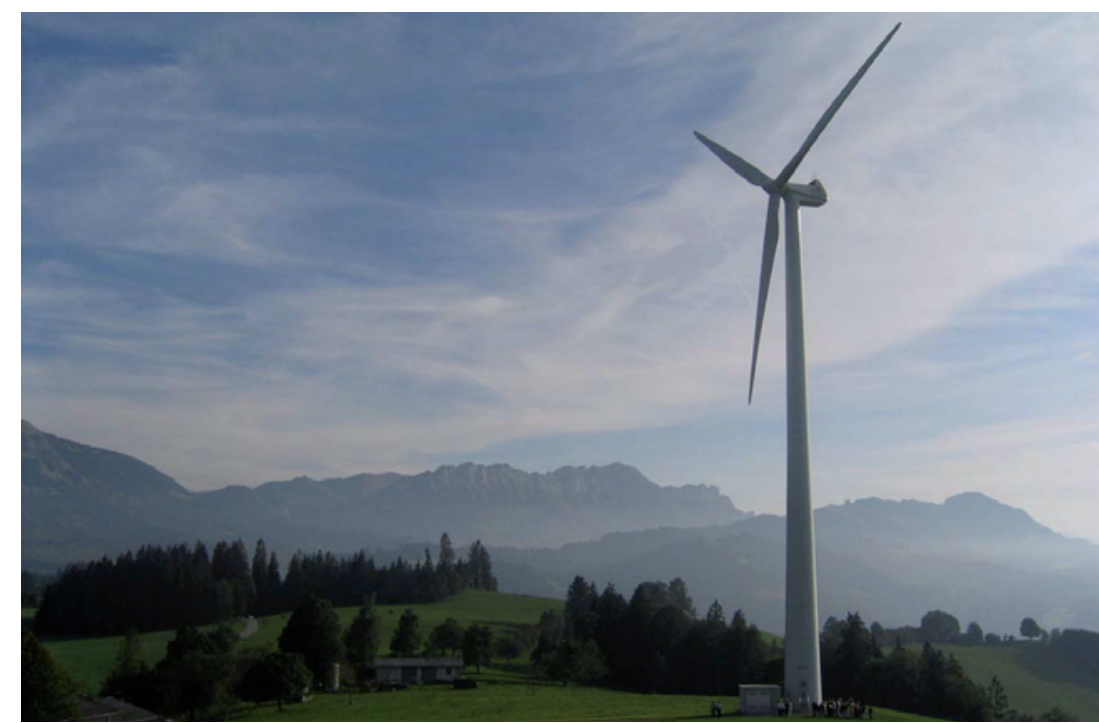

Wind turbine. UNESCO Biosphere Reserve Entlebuch. (C) Suisse Éole

demand for sustainable use of forests. In France, the regional nature parks expect an increase in conflicts in the near future due to state subsidies for the use of biomass. In other regions, for instance in the Binntal Regional Nature Park, the park management considers the potential for using wood underexploited.

Photovoltaic plants: Smaller facilities related to existing buildings can be realized without difficulties in most parks. In France, however, objections are being raised from an architectural point of view. So far, most parks have not been confronted with the issue of establishing larger facilities. In Großes Walsertal BR, however, a large pilot plant has been built and widely accepted by the population. An increased promotion of photovoltaic plants may heighten the potential for conflict.

How to avoid or reduce conflict: some examples

The mission statement of Großes Walsertal BR contains targets for generating energy from renewable sources as well as for a responsible and economical use of energy and resources. The BR is committed to the e 5 programme for energy-efficient communities and annually defines measures in this respect. The e 5 programme for energy efficient communities was initiated in 1998 by the Austrian federal province of Vorarlberg. Presently, 17 communities in Vorarlberg and Großes Walsertal BR are engaged in the programme, which aims at a particularly progressive energy policy. Within the eRegio project the park management identifies options for action and potentials and formulates an implementation concept with concrete measures for biomass, hydro-electric power, energy efficiency, mobility and communication. The eRegio project was initiated by Großes Walsertal BR and is supported by the Austrian Climate and Energy Fund. The vision of the project is to establish the region as a region not only self-sufficient in (renewable) energy but actually able to export a surplus.

In Switzerland, the Pfyn-Finges and the Binntal Regional Nature Park are developing energy concepts. 
These concepts are an attempt to face rising demands for energy production from renewable sources. The concept aims to increase energy production from renewable sources without compromizing nature and landscape values.

In 2001, the Val Müstair (part of a BR since 2010) formulated a protection and utilization plan that has been ratified by the federal authorities. With this plan it reacted to the conflicts about the use of water for energy generation. Central to the plan is the delineation between usable and protected river basins. The protection and utilization plan helped to reduce the tensions between inhabitants with differing views, as well as between representatives of opposing interests.

\section{Conclusions}

Park managements have limited means to deal with conflicts related to energy production from renewable sources. In the absence of legal regulations, parks often have no competences to take an active role in the planning of energy production facilities. Nevertheless, park managements assess the need for regulation differently. Whereas some parks would prefer precise and clear legal regulations, others reject additional rules. Park managements often follow defensive or passive strategies, particularly where clear regulations are missing. However, the examples given above show that proactive strategies are possible.

There is no remedy that applies to all parks. The need for action varies, depending on the potential for conflict. The following measures may contribute to reducing conflicts:

- planning authority should inform park authorities better on planned projects;

- involve park managements in the project planning process;

- analyse the needs and expectations of the population; - establish regional energy targets and energy concepts including the park area (cooperation between park management and political authorities).

Given current developments, it seems unavoidable that protected areas should have to address the question of renewable energy. In view of the already existing and probably increasing conflict potential, parks should have strategies at hand on how to deal with projects for the production of renewable energy.

\section{Acknowledgements / Funding}

We would like to acknowledge the following contributors:

Austria: Werner Franek, Gesäuse NP; Ruth Moser, Großes Walsertal BR; Thomas Steiner, Hohe Tauern NP; Thomas Schmarda, Ötztal Nature Park \& Katharina Peer, Tyrolean Nature Conservation Areas

France: Audrey Matt, Baronnies Provençales Regional Nature Park; Fabien Bourhis, Chartreuse Regional
Nature Park; Serge Charruau, Vercors Regional Nature Park \& Dominique Imburgia, Verdon Regional Nature Park

Germany: Robert Heuberger, Berchtesgaden NP

Italy: Massimo Corradi, Adamello-Brenta Regional Nature Park; Graziano Danelin, Friulian Dolomites Regional Nature Park \& Elio Tompetrini, Gran Paradiso NP

Switzerland: Amadé Zenzünen, Binntal Regional Nature Park; Dieter Müller, Ela Regional Nature Park, Florian Knaus, Entlebuch BR; Christine Scheidegger, Gantrisch Regional Nature Park; Alexandra StaubFuccaro, Pfyn-Finges Regional Nature Park; Beat Ruppen, Swiss Alps Jungfrau-Aletsch UNESCO WHS; Stefan Müller, Thal Regional Nature Park \& Hansjörg Weber, Val Müstair BR

StephanieStotz (Swiss Academy of Sciences,SCNAT) Elena Maselli and Laura Savio (ALPARC)

Funding for this project was provided by the Swiss Federal Office for the Environment FOEN.

Source: Erneuerbare Energien in Pärken der Alpen. Énergies renouvelables dans des parcs des Alpes. Energie rinnovabili nelle parche alpine. $d / f / i$. Akademien der Wissenschaften Schweiz. Académies suisses des sciences. Accademie svizzere delle scienze. Bern. 90 p.

Further information: esther.volken@scnat.ch

\section{Authors}

Esther Volken ${ }^{1}$

lic.phil.nat., scientific officer at the Swiss Academy of Sciences, working for the Forum for Climate and Global Change. esther.volken@scnat.ch

\section{Thomas Scheurer'}

Dr., Executive Secretary of the International Scientific Committee on Research in the Alps (ISCAR,) and of the Research Council of the Swiss National Park; both located at the Swiss Academy of Sciences. thomas.scheurer@scnat.ch

\section{Guido Plassmann²}

Dr., Director of the Task Force "Protected Areas" of the Permanent Secretariat of the Alpine Convention coordinating ALPARC, the Alpine Network of Protected Areas. guido.plassmann@alparc.org

\section{Astrid Wallner}

Dr., until 2010 regional coordinator 'Swiss Alps' of the NCCR North-South and research associate of the UNESCO World Heritage Swiss Alps Jungfrau-Aletsch at the University of Bern. Since 2010 Executive Secretary of the Swiss Park Research Coordination at the Swiss Academy of Sciences. astrid.wallner@scnat.ch

\footnotetext{
${ }^{1}$ Swiss Academy of Sciences (SCNAT), Schwarztorstrasse 9, 3007 Bern, Switzerland.

${ }^{2}$ Alpine Network of Protected Areas (ALPARC), 256, rue de la République, 73000 Chambéry, France.
} 